\title{
Education as a Tool for Peace? The King Abdullah Scholarship Program and Perceptions of Saudi Arabia and UAE post 9/11
}

\author{
Kholoud T. Hilal ${ }^{1} \&$ Brian D. Denman ${ }^{2}$ \\ ${ }^{1}$ UNE School of Business, University of New England, Armidale, Australia \\ ${ }^{2}$ School of Education, University of New England, Armidale, Australia \\ Correspondence: Kholoud T. Hilal, UNE School of Business, University of New England, Armidale, NSW 2351, \\ Australia. Tel: 61-2-6773-5062. E-mail: khilal@une.edu.au
}

Received: January 3, 2013 Accepted: January 20, 2013 Online Published: March 25, 2013

doi:10.5539/hes.v3n2p24 URL: http://dx.doi.org/10.5539/hes.v3n2p24

\begin{abstract}
Since 9/11, Saudi Arabia has made significant attempts to change its public image because of its alleged association with global terrorism. Given its charitable interests in promoting education as a tool for peace within the Arab region, it has established the King Abdullah Scholarship Program (KASP), considered to be the most heavily endowed overseas scholarship program ever offered by a nation-state. Since 2005, over 120,000 Saudi university students have been financed by this scholarship to pursue their university studies abroad.

This investigation concerns student perceptions of Saudi and Emirati students studying abroad ten years after the tragedy of 9/11. It draws from 30 face-to-face interviews of international students in Australia about their perceptions and viewpoints of Saudi Arabia and the Arab World pre- and post 9/11. It centers on Saudi and Emirati students and suggests that education can be a tool for peace.
\end{abstract}

Keywords: Saudi Arabia, UAE, student mobility, education for peace

\section{Introduction}

Education, in its definition, is generally associated with types of schooling and curricular content. In recent times, however, the concept of education has been confronted by globalisation pressures and standardising quality control and performance-based measures in terms of teaching, learning, and assessment. There has been little attention given to its underlying purpose - particularly in certain pockets of the world.

In this study, there is question whether cross-border education can be considered as a tool for peace based on the expectations and experiences of Saudi and Emirati students studying in Australia in 2011. The principal author of this study is a Saudi PhD student studying in Australia who conducted a pilot study of student perceptions while researching Saudi student mobility based on the KASP program. In the process, and following a review of the literature, she decided to consider whether student mobility as a form of self-education-building and through international student interaction might be identified as tools for peace. As a premise, investigations such as this require a relaxing of preconceived notions and bias of what education is and the necessity of thinking more broadly about one's cultural heritage, background, identity, worldview, and ways of thinking. It also presumes that agency has the motivation, will and capacity to instinctually strive for and build upon peace or has the potential to do so despite any odds against it.

Here, it is appropriate to provide background on the context, views, and ancillary writings of the principal author as she seeks to develop understanding of her research motivation:

\section{Background on the Context, Views, and Ancillary Writings}

\subsection{Perceived Views about Globalisation and Media}

"Globalization has certainly been the most widely used and misused keyword in disputes of recent years and will be of the coming years too" (Beck, 2000, p. 19). In defining globalisation, it appears that there are at least three distinguishable dimensions: economics, environment and, in terms of relationships, between countries and people. Despite the positive and negative impacts of globalisation on a global scale economically as well as environmentally, many scholars have questioned its role. For example, is globalisation supposed to unify, integrate, and provide greater connections in the world? Is globalisation providing greater effectiveness or destructive tendencies to countries or nation-states? 
Generally speaking, globalisation is perceived to link the world into tighter relationships between culture and people, and supposedly diminishing borders between countries and communications. Normatively speaking, globalisation should be a process that integrates different societies in positive ways. McGrew contends that globalisation constitutes a:

Multiplicity of linkages and interconnections that transcend the nation states (and by implication the societies) which make up the modern world system. It defines a process through which events, decisions and activities in one part of the world can come to have a significant consequence for individuals and communities in quite distant parts of the globe (McGrew, 1998, online).

According to Basiga, globalisation is “... the actual universalisation and commodification of knowledge, technology and communication, culture, health care, heritage, genetic codes, and natural resources such as land, forests, air, and water" (Basiga 2004 from http://www.educ.ualberta.ca/css/Css_38_3/ARbasiga_globalization_peace.htm). Featherstone also stresses the role globalisation plays in gathering dissimilar cultures together to diminish the importance of geographical borders. He states:

The process of globalization suggests simultaneously two images of culture. The first image entails the extension outward of a particular culture to its limit, the globe. Heterogeneous become incorporated and integrated into a dominant culture which eventually covers the whole world. The second image points to the compression of cultures. Things formerly held apart are now brought into contact and juxtaposition (Featherstone, 1995, p. 6).

Unfortunately, these definitions reflect positivists' points of view. By looking - with realistic eyes and with honest hearts of a 'one world scenario' - one may notice that there still are many cultures and nations left to fend for themselves, are marginalized and disrespected. Undoubtedly, the media has been having a powerful and significant role to play in promoting globalisation. The McBride Commission, which was set up in the late 1970s by the UNESCO to create a New World Communications Order, was undermined by Western powers to maintain their control on how information is and should be distributed around the world. Hence, to an extent, countries situated outside the spheres of influence from the West are influenced in the way global media disseminates information.

From an outsider's viewpoint, global media from the West tends to shed light only on certain types of events. For example, it frames the news of developing countries only in terms of natural disasters such as (floods, earthquakes and famines) and ignores other events that may contribute to such natural disasters (i.e., political conditions or economic development issues, such as government corruption or the lack of international investment in public services and economic development) (Mowlana, 1985).

Norris et al added:

The adoption of 'episodic' frames, focusing upon the specifics of any particular event, has also been applied to understand typical news coverage of political issues, including the Gulf War, crime, poverty, and Iran-Contra, along with the neglect of 'thematic' frames providing a broader and more contextualized understanding of the background factors contributing towards these issues (Norris at al., 2003, p. 8).

With more emphasis on the relationships between the West and Muslims, the popular anthology (produced by The Outreach Center in 1998) declares that Middle East and Middle Easterners are poorly understood by the West and particularly in the United States because of the misrepresentations and stereotypes expressed in the media - especially when media represents Islamic Fundamentalism or terrorist attacks by some Muslims or Middle Easterners. It is assumed that "the perpetuation of such stereotypes is a major obstacle to better understanding of the region and improved international and intercultural relationships" (Ibid, p. vii). Apparently, the news media is the only source of information identifying Middle Easterners and most of which are unluckily derogatory and negative. Accordingly, the wealth of human experience and the embrace for cultural relativism are both denied. The authors from the anthology state:

While educators have, throughout the last decade, come to see Multiculturalism and Global Studies as top priorities, the material available on the Middle East is mostly historical or political in nature... but it does not go far enough in breaking down barriers to cultural understanding (Ibid, p. vii).

Personally, only the media can be accused for consolidating and concocting negative perceptions of Gulf Arabs (Note 1) in the West, particularly with issues such as terrorism and religious fanaticism, and stereotypical generalizations such as oil-rich, desert nomads, and camelback riders.

According to a recent study in 2009, the hegemonic media used to be heavily dominated by the United States, however, it becomes more globalised now by other countries such as France, Germany and Australia. Still one 
can see that the media is still controlled by the West. Subsequently, people in diverse spots of the globe have become fully aware of the West's power over media which can affect civilization-building, lifestyles, cultures, customs, and rituals. Some writers are amazed at how globalisation has made people become accustomed to eating the same food, watch the same movies, and listen to the same music (Hochschild, 2006).

In sum, the globalisation of media has failed in connecting and integrating the developing countries with the developed countries. In other words, globalisation through the media "results in largely unilateral gains" (Basiga 2004 from http://www.educ.ualberta.ca/css/Css_38_3/ARbasiga_globalization_peace.htm) and undermines basic cultural understanding or awareness. Beck describes this as a 'one-way street' (Beck, 2000).

\subsection{Perceived Views of Globalisation and the Three Worlds in One}

With economic globalisation, the world has been promised to be a more prosperous world, as developed countries have increased trade with developing countries in an attempt to improve standards of living; it is supposed to be a 'win-win' situation. Sadly, economic disparities have been enhanced not only for developing nations but also in pockets of developed nations. As such, economic globalisation appears to be prosperous for some but not the whole. Gaps are widening between First, Second, and Third Worlds and with fragmented inequities found in each.

Ironically, many scholars contend that globalisation began as early as the end of the $19^{\text {th }}$ Century CE during the advent of the Industrial Revolution. The era of modernisation promoted greater relationships between and amongst countries and nations, but it was only in the $20^{\text {th }}$ Century around WWII when issues of 'development', 'developing', and 'underdeveloped' came into being with descriptors that ultimately divided the world into three parts: First, Second and Third World Countries. This division continues to be contentious and makes perfect nonsense (One World - Nations Online). It has unfairly divided the world into social class that undermines identity and the very world for which they belong. For example, First World countries can be attributed to being classed as first class human beings, who are provided with both the primitive as well as luxurious needs of life. Third world countries can be classed as human beings who can hardly provide for themselves with the most basic needs such as food and shelter. It is sad to view the hegemonic struggle of one over others and to learn that those who are born and raised in a privileged 'nation' are critical and judgmental of others who are not only misunderstood butoften deprived. Finally, ranking humanity on the basis of human condition as well as racial and ethnic attributes (i.e., nationalities, religion, power and color) create an "us" versus "them" mentality (Salomon, 2004).

Third world countries are often classified synonymously with poor countries or developing/under-developing countries. As an example, Gulf Arab States are listed as Third world countries (see Figure 1), although the Kingdom of Saudi Arabia, Qatar, Kuwait and the United Arab Emirates are four of the richest countries in the world according to GDP. While many of these countries have acquired their newfound wealth post WWII, the issues of development raises serious questions about the credibility of such descriptors.

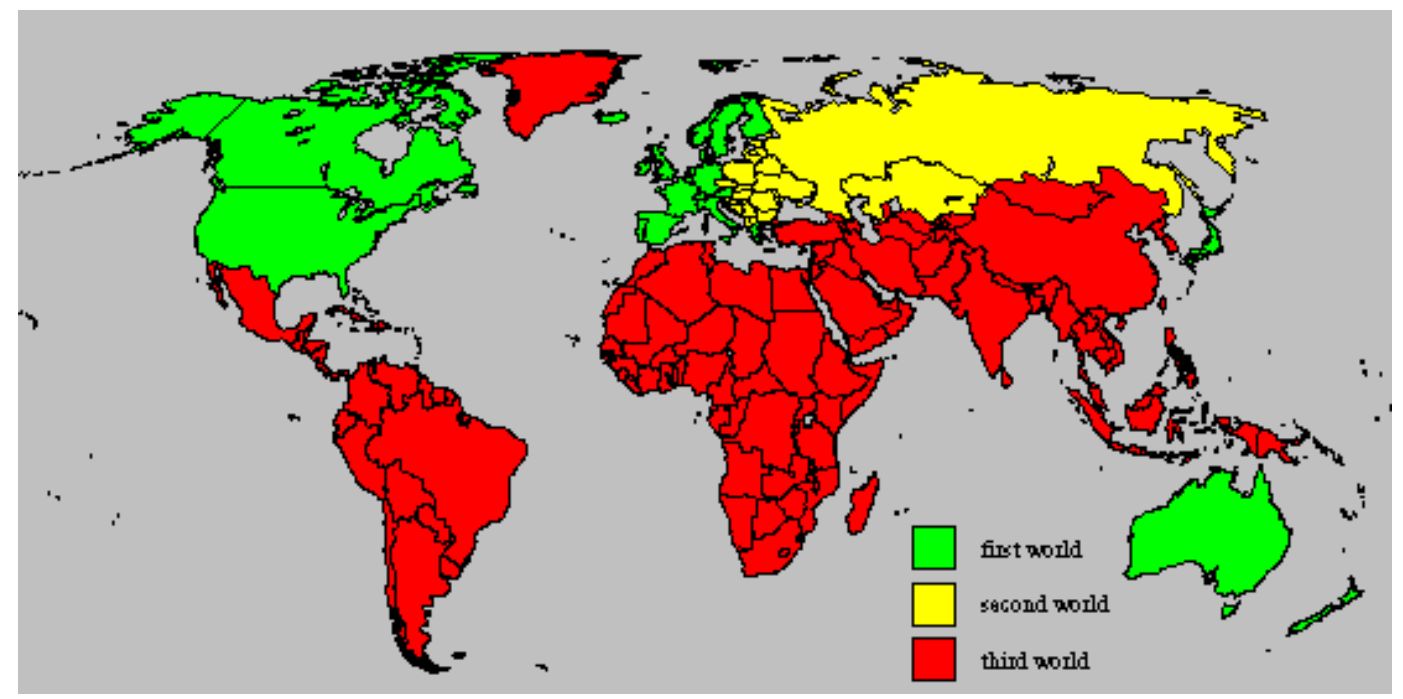

Figure 1. The Three Worlds Model
Source:
Three-World
Model.
Accessed
January
29 ,
2013,

http://www.uwec.edu/geography/Ivogeler/w111/3world.htm 


\section{Could Peace Education Cure the Wounds?}

Although the challenges and conflicts between countries, cultures, and religions vary according to sociopolitical contexts (Salomon, 2004), the benefits of peace education described below provide a sense of hope that can amend and/or reconcile the damaging, negative impacts of globalisation, help close the gap/s between cultures, and consolidate the three worlds into a more harmonious one.

According to Harris, peace education is based on a process of enlightening people about the threats of violence and teaches strategies for peace. He adds that formal peace education is based on written instructions through schooling institutions (Harris, 2008, pp. 15-16). It is seen as an innate dynamic within human agency that can be characterised by concord and harmony, where the resolution of conflicts are relied upon by mutual respect on differences of race, religion, color, genre and nationality (Azcona: online from http://www.eolss.net/Sample-Chapters/C04/E1-39A-17.pdf). In UNICEF, peace education refers to a process that promotes the knowledge, skills, values and attitudes that are needed to bringing about behavioural changes that help children, youth and adults to avoid and prevent violence. This process helps to resolve conflicts peacefully and to build the conditions favourable to peace (e.g., intrapersonal level, interpersonal, intergroup, national or international level) (Fountain, 1999, p. 1). Harris defines peace education as a moral education that “... tries to inoculate students against the evil effects of violence by teaching them skills to manage their conflicts nonviolently and by motivating them to choose peace when faced with conflicts" (Harris, 2003, p. 7-9). Finally, peace education ensures peace within and between countries... it can help in the development of social harmony, equity, and social justice as alternatives to wars and rising conflict. The crucial element found in peace education, regardless of definition, coaches people to exercise their economical, political and social rights equally (Basiga, 2004).

When the right to life and viable community is threatened anywhere, by nature, social, or political cause, we have a common goal and a common responsibility to protect and support those who are threatened (DePass et al., 1991, p. 1-2).

When one hears about conflict or war, there are at least two sides/parties involved in the matter. Hence, we may ask ourselves how could peace education succeed if it is taught or perceived as one-sided? Does that indicate that peace education is doing half its job? Even in countries that are implementing and promoting peace education, how many students are studying the subject and how many thousands of people even know about peace education?

Essentially, in terms of international or ethnic conflicts, peace education will perhaps struggle to adhere to its noble mission in "clearing up the skies" between conflicting groups. Despite the challenges, people should not question nor underestimate the role of education as tool for peace; however, it must be acknowledged that education could also be considered a tool for conflict.

\section{Literature Review}

\subsection{Example from Previous Study on Education as Tool for Peace}

Some educators try to prove that peace education can be tool for peace even when the relationship is intense and sometimes subjected to deadly conflict. Examples include Israel and Palestine, North and South Korea, Sudan and South Sudan. Research conducted by Gavriel Salomon of Israel's University of Haifa considers the effects of peace education in the Palestinian-Israeli context. The investigation illustrates in detail the mechanism and steps of the programs that were designed to describe peace education impact in the context of intractable conflict. In sum, one of the nongovernmental organisations (NGOs) in Israel, the Israeli-Palestine Center for Research and Information (IPCRI) conducted programs for peace education in both Palestinian and Israeli high schools. It was a 3-day workshop at the Givat Haviva compound by studying conflict elsewhere. One of the programs was teaching peace education by studying conflict resolution elsewhere in the world. Northern Ireland was chosen as a case study. $11^{\text {th }}$ graders were selected to participate in this program from Palestine and Israel high schools ranging from 16 to 17 years of age.

These students were not asked to present/produce analogies about their local conflicts but instead what they learned about the collective narratives of the two sides in Northern Ireland. The educators observed that “... exposure to the Northern Ireland conflict and the two-sidedness of claims and beliefs - so transparent to an outsider yet so opaque to defensive insiders - enables outsiders to detect similar qualities in the conflict that they are" (Salomon, 2004, pp. 13-14)

From the onset of the program, Israeli and Palestinians students initially did not want to talk to one another, but at the end of the workshop, students developed closer ties, a mutual understanding, and friendships from both sides (Salomon, 2004, pp. 257-269). This is not to say that peace education is the 'be all end all', but it does engage people to work collectively and constructively. 


\subsection{Theory}

Not everybody lives in the same world. (Feyerabend, 1987, p. 104)

In its broadest form, the strength of education as a field of study is in its interdisciplinary nature, yet despite its varied usage of different methodologies, particularly in the social sciences (e.g., psychology, sociology, anthropology), it is often plagued with subjective interpretations of policy and practice and hotly contested over validity and context. Oftentimes, objective structures (frameworks and/or approaches) are rigourously sought after to uncover educational phenomena in systematic ways, but there is no one methodology, design, or approach that can assist with distinguishing between cultural and social worlds nor find meaning in educational mechanisms that tend to reproduce or transform individuals or society.

\begin{tabular}{|c|c|c|c|c|}
\hline & Collaborative & Inquiry-Based & Advocacy-Based & Rationalistic \\
\hline $\begin{array}{l}\text { Theoretical } \\
\text { framework(s) }\end{array}$ & $\begin{array}{l}\text { Symbolic } \\
\text { Interactionism; } \\
\text { Cultural Relativism }\end{array}$ & $\begin{array}{l}\text { Constructivism; } \\
\text { Pragmatism; } \\
\text { Phenomenological }\end{array}$ & Neo-Populism & $\begin{array}{l}\text { Idealism; } \\
\text { Positivism; } \\
\text { Normativism }\end{array}$ \\
\hline Learning approach & $\begin{array}{l}\text { Interactive with } \\
\text { others and self; } \\
\text { group-oriented }\end{array}$ & $\begin{array}{l}\text { Collaborative } \\
\text { problem solving; } \\
\text { critical thinking }\end{array}$ & $\begin{array}{l}\text { Persuasive and/or } \\
\text { lobbying for a cause } \\
\text { or direction based on } \\
\text { majority rules }\end{array}$ & $\begin{array}{l}\text { Argumentative; } \\
\text { interventionistic; } \\
\text { mechanistic; } \\
\text { structural }\end{array}$ \\
\hline Participants' role & $\begin{array}{l}\text { Projection of self } \\
\text { and society to } \\
\text { reflect a particular } \\
\text { way, orientation, or } \\
\text { construct }\end{array}$ & Critical thinkers & $\begin{array}{ll}\text { Spokespeople for the } \\
\text { 'majority' usually } \\
\text { through media }\end{array}$ & $\begin{array}{l}\text { Firmly held stances } \\
\text { based on testing, } \\
\text { empirical } \\
\text { verification, and } \\
\text { accountability }\end{array}$ \\
\hline $\begin{array}{l}\text { Patterns } \\
\text { behaviour }\end{array}$ & \begin{tabular}{lr} 
Self & dependent \\
upon society and \\
vice & versa; \\
emphasis & on \\
prevailing values \\
and standards of \\
\multicolumn{2}{l}{ society }
\end{tabular} & $\begin{array}{lr}\text { Understanding } & \text { is } \\
\text { based } & \text { on } \\
\text { interactions } & \text { with } \\
\text { environment; } \\
\text { dissonance } \\
\text { stimulates learning; } \\
\text { knowledge evolves } \\
\text { through } \\
\text { negotiation }\end{array}$ & $\begin{array}{lr}\text { Persuasion of others } \\
\text { to accept } \\
\text { viewpoint/perspective; } \\
\text { defencerand } \\
\text { justification of stance; } \\
\text { downplay weaknesses }\end{array}$ & $\begin{array}{l}\text { Legitimisation and } \\
\text { justification of facts } \\
\text { through existing } \\
\text { bodies } \\
\text { information; of } \\
\text { pre-occupation with } \\
\text { preserving identity } \\
\text { or ideology }\end{array}$ \\
\hline Minority views & $\begin{array}{lr}\text { Opportunistic } & \text { but } \\
\text { co-operative } & \text { if } \\
\text { negotiated } & \end{array}$ & $\begin{array}{l}\text { Cultivated } \\
\text { valued }\end{array}$ & $\begin{array}{l}\text { Discouraged } \\
\text { dismissed }\end{array}$ & $\begin{array}{l}\text { Restricted, } \\
\text { excluded } \\
\text { alienated }\end{array}$ \\
\hline $\begin{array}{l}\text { Scholastic } \\
\text { contributors }\end{array}$ & Jarvis; Feyerabend & $\begin{array}{l}\text { Dewey; } \\
\text { Montessouri; } \\
\text { Plato; Husserl }\end{array}$ & & Plato; Hegel \\
\hline
\end{tabular}

Figure 2. Illustrations of learning behaviour approaches based on social reproduction

Sources: Savery \& Duffy (2001); Jarvis (2007); Bowen \& Hobson (1974).

Figure 2 attempts to categorise select ways of thinking that highlight divisions in the ways people learn and socially construct their respective identities and realities. Although these categories of learning behavior are purposely oversimplified to demonstrate variation, the intent is to identify social structures in the way education is perceived and pursued. Such approaches are generally practiced and refined through schooling and learning acquisition throughout life, but may also be influenced by cultural considerations as well. By distinguishing between social worlds of 'ways of thinking', one may be able to uncover dissonance or discord during unspecified periods of conflict, threats, or risks.

The adage, 'learn by doing', the idea that education could be conceived and attained without formal education 
but through training and development and 'hands-on' learning, received great fanfare in the mid-1990s, but Nonaka and Takeuchi developed the concept one step further as a 'knowledge conversion' model (Figure 2). This model, which adds to Polanyi's personal convictions of tacit knowledge, “... we can know more than we can tell" (Polanyi, 1967, p. 4), distinguishes knowledge interaction between tacit to tacit, tacit to explicit, explicit to explicit, and explicit to tacit (French, online). It is the belief that through conceptual and sensory information, which is collected and synthesized in an individual's thought processes, can lead toward an increased understanding and more compelling responsibility to act on peace when confronted with controversy or conflict.

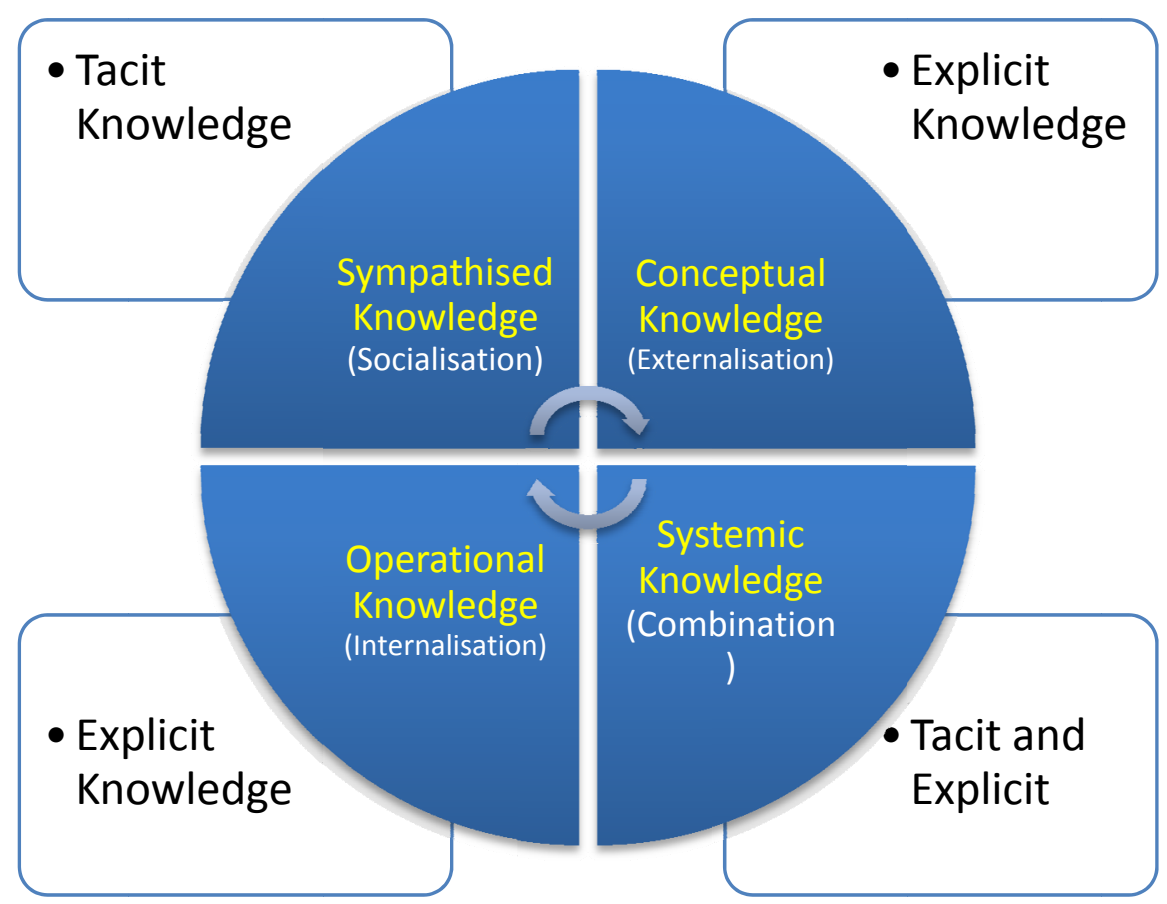

Figure 3. Modes of knowledge conversion

Source: Nonaka and Takeuchi 1995 in French: online.

According to Nonaka and Takeuchi $(1995$, p. 63), the acquisition of tacit knowledge generally relies on the shared experiences of an individual who can generate understanding through the projection of another's thinking process (socialisation). Explicit knowledge is dependent on the use of analogies and metaphors to apply more analytical constructs and concepts through the process known as externalisation and, when both converge and converse with one another, the process of combination takes effect. This process links explicit knowledge into other forms of explicit knowledge. When an individual reaches the internalisation process, explicit knowledge becomes embedded from within individuals and is retained (in French, online). What appears most useful with this conversion model is the importance of active interaction and engagement. This suggests that when dealing with cultures other than one's own, that it is essential to interact, communicate, and engage. It is therefore postulated that the act of student mobility through study abroad might be considered. Study abroad requires an individual to actively engage with others as part of their overseas experience at a hosting institution. This helps to improve language acquisition and build on an individual's self-efficacy. Figure 3 helps to describe how students perceive 'global awareness' through Opper et al study of US study abroad students and non-participating students. 


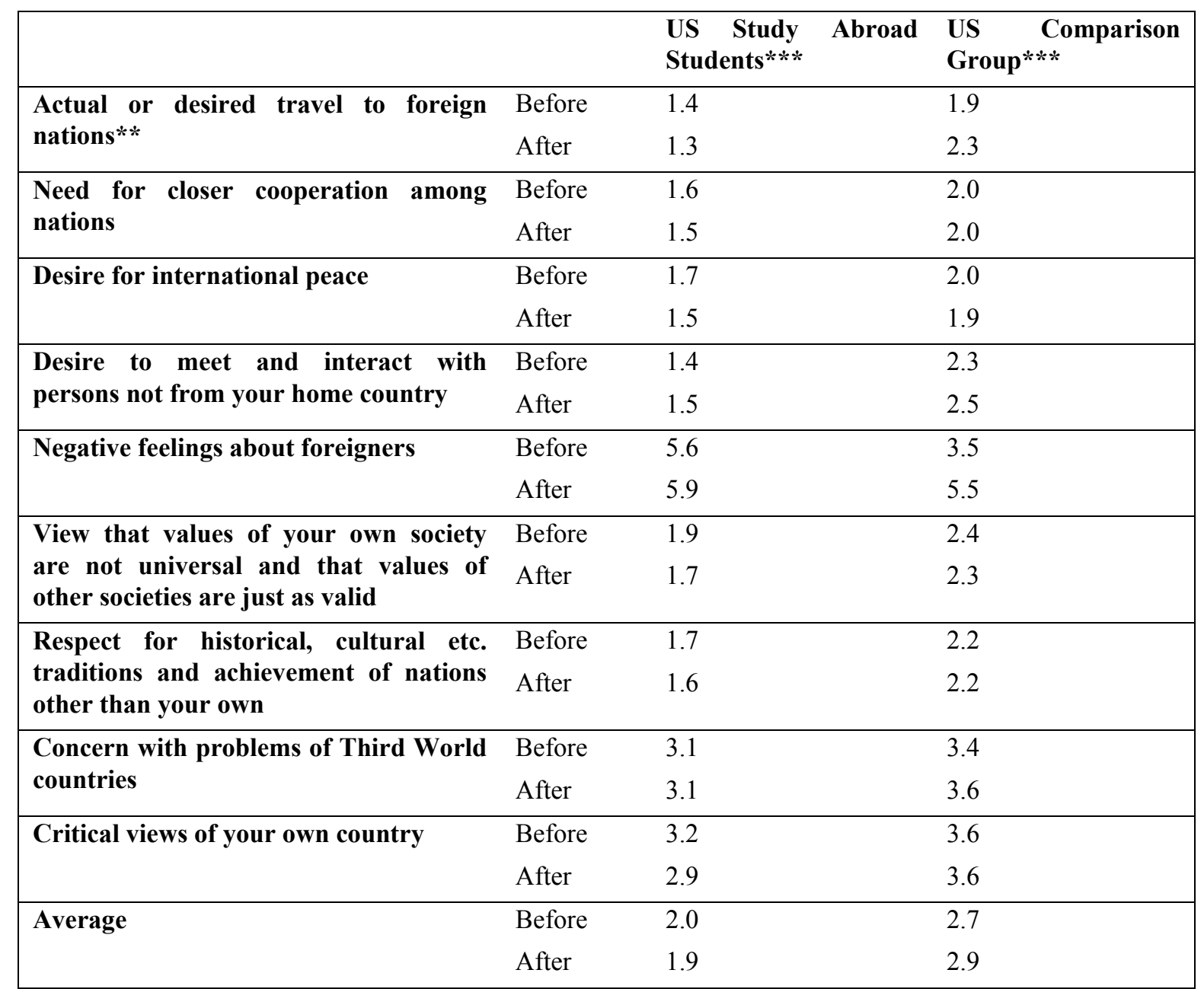

Figure 4. US study abroad participants' global awareness* in comparison with US non-participating students (in arithmetic means)**

* Scale from 1= 'considerable' to 5- 'non-existent' (question: "How would you describe your position on the following?")

** The sequence of categories does not correspond the questionnaire, but rather is a rank order according to replies prior to the study abroad period

Source: Opper et al., 1990, p. 132.

In this particular study, Opper et al were able to demonstrate that global awareness of Americans who participated in study abroad was considerably higher than that of the students who did not participate. The desire for international peace was marginally higher for the non-participating students versus a significant increase in those who partook in study abroad. This seems to suggest that student mobility does serve as a catalyst for improving one's outlook and perspective on global events and interest in international cooperation and understanding.

Personality development also plays a role, but instead of seeking intellectual achievement by scaffolding patterns of learning behavior or converging tacit and explicit knowledge, Mroz (2009) believes that human development and hence, education, should strive for individuals to be all that they want to be, rather than who one is, through the development of their personality. Dabrowski's Theory of Positive Disintegration addresses varying levels of personality development and their characteristics over time (Ackerman, 2009); (Alvarez-Calderon, 2010). However, Mendaglio adds to Dabrowski's Theory, identifying three factors affecting human development. These factors include heredity, environmental and social influences, and “. . the force by which individuals become more self-determined, controlling their behaviours through their inner voices and values" (Mendaglio, 2008, p. 26). This form of self-learning involves the maturation “... process of working out the personality in one's inner 
self" (Dabrowski, 1972, p. 62). By products of a fully developed personality include empathy, altruism, and prosocial behavior. The overarching question is whether these three factors impact our understanding of education and peace. It is believed that the complex interaction between an individual's learning behavior coupled with knowledge acquisition and personality 'human' development define and shape an individual's perception of 'other', perceptions of other cultures, worldview, and identity.

\section{What Was the Emphasis and Overall Purpose of the Study?}

When speaking about the Middle East, it is important to point out that "Middle East" is a term that was popularised by an American naval officer named Alfred Thayer Mahan in 1902, but it also might have been used by the British Foreign Office in London to distinguish between parts of its colonial dominion (Davison, 1960 in Are you listening? Voices from the Middle East 1998). In other words, referring to Arabs and Arabs' region as Middle East needs to be reconsider, and this term may be useful particularly and mainly in a political context only. The issue of why the Middle East is called the Middle East is an interesting example of how simple geographic names are enmeshed in geopolitics and can shift in meaning over time (Davison, 1960).

Based on the information above, the author - through this study - attempts to help the West to 'scratch the surface' and expand their knowledge about Gulf Arabs precisely. The Gulf Cooperation Council (GCC) is a political and economic union of Gulf Arab States, which gather annually in Riyadh (the Capitol of Saudi Arabia) In 2010, for example, the members of the GCC decided to establish a unified currency called the "Khaliji", however, this has not been enacted yet at this point in time (Al-Sharif online; Sturm, 2005).Hopefully, this study will participate and cooperate with peace educators' works in bringing the heterogeneous diameters of this planet together. Moreover, the interviews aim to express that those Arabs do not see Westerners or non-Muslims as enemies but instead they apparently appreciate the West development and they try to catch up with them. This study also proposed to measure whether or not student mobility can work as the most effective technique of peace education or peace-building as it brings two opposite sides 'under one roof' and gives them opportunities to correct and explain any misperception and/or misunderstanding. Student mobility connects people and connects thoughts that come from different backgrounds in possible harmonious atmospheres (educational institutions).

\section{Methodology}

Many researchers strive to design studies that will not only give a multidimensional perspectives of the phenomenon (Foster, 1997) but will also provide rich, unbiased data that can be interpreted with a comfortable degree of assurance (Breitmayer, Ayres, \& Knafl, 1993). This study began with an online survey in which over 300 Saudi and Emirati overseas students participated. Focus groups and interview techniques were used as well. The interviews were intended to uncover 'truth', review 'realities' and provide information in depth. (It is believed that one way to increase the validity, strength, and interpretative potential of such a study, decrease investigator biases, and provide multiple perspectives is to use methods involving triangulation (Denzin, 1970)). This approach was also useful in the fact that the conversation could be directed more or less toward the researcher's plans for the data and could be seen as a specific kind of interaction in which the researcher and interviewee could produce framework about beliefs, behavior, ways of classifying the world, and/or about how knowledge is categorized through a more personalised, conversational approach (Green \& Thorogood, 2004; Minichiello et al., 2008).

This current study is based on the results and retrieved from qualitative, unstructured, and semi-structured interviews; however, the structured interview was the most appropriate approach for this study and therefore the main technique utilized. It is also known as 'standardised' or as a 'survey' interview. It is primarily useful for social scientists.

In this study, an open-ended question format was used which enabled the researcher to discuss a number of the on-line survey's questions in more depth and enabled her to better understand the students viewpoints.

\subsection{The Sample}

While the sample size was small, interviewing the students worked to triangulate the data that are given from the on-line survey and the focus groups. 30 Saudi and Emirati students were interviewed in different states of Australia. There were 16 Saudi students participated in the interview; 11 male students and there were only 4 females. (Disclosure: the four females were close friends of the researcher and most of other females were not willing to participate!) 
14 UAE students were interviewed in three main cities of Australia. With UAE's students, it was very obvious that the majority of the UAE's students are single; unfortunately the researcher could not reach any UAE female students, so the 14 interviewed students consisted of males only.

Whilst there were commonalities and slight differences tables between Saudis' and Emiratis' responses, it is important to note that all $14 \mathrm{UAE}$ students were undertaking bachelor-level degrees whereas the 16 Saudi students were in bachelor to $\mathrm{PhD}$ programs.

\subsection{Locations}

Because the sample size is small, the researcher purposely chose to interview students living in different locations. The objective of this strategy was to avoid interviewing friends from one city where a certain belief, problem, benefit or phenomenon dominates.

Accordingly, a few interviews were conducted in the states of New South Wales (Armidale) and the majority of Emirati students are found in the states of Queensland (Brisbane) and Victoria (Melbourne). 8 interviews of Saudi and Emirati students took place in South Australia (Adelaide). Interestingly, Saudi students were located in every city whereas the majority of UAE's students were located in Brisbane and Melbourne with only a handful (5) students studying in Adelaide.

\subsection{Significance and Limitations of This Study}

Given the extenuating circumstances between East and West ideologies and hegemonic struggles post 9/11, this study explores ways forward through the perceived views of Saudi and UAE students studying abroad in Australia in 2012. Its significance lays in the important role student mobility plays in bridging gaps between divergent groups/nations and promoting diplomacy through student interaction. The students' responses indicate a willingness and eagerness in adopting Western culture but the study also reveals initial misperceptions about the West before going overseas.

Moreover, due to the scarcity of available data concerning higher education in the Gulf region, this research appears as very useful for the outsiders. Although King Abdullah scholarship Program is the hugest one of its kind worldwide, it is not covered by researches. It deserves extensive analysis to discuss its different impacts, systems and goals. In terms of the impacts of the student mobility on enhancing the relationships and correcting the stereotypes between the Gulf Arabs and the West, As far as I know, this is the only research discusses it.

There is one limitation to this study: The sample is too small to generalize realiable facts. Additional research, particularly that which addresses students of other cultures living/studying in the Middle East is needed in order to compare and contrast their experiences with the population included in this research.

\section{Contextual Issues Related to the Data}

In order to better understand Gulf Arabs, the analysis of Figure 5 below encompasses a brief explanation or justification of the questions answered in the interviews conducted. With the emphasis placed on personal benefits, the ranking of certain aspects of respective lifestyles, beliefs, interests or norms are analysed within each cultural/national context in order to ascertain why a particular point is of importance to respective groups of students.

'Emirati students', 'Emiratis' and 'UAE's students' will be used interchangeably and likewise with 'Saudi students', 'Saudis' and 'KSA's students'. Again, while only Saudi Arabians and Emiratis are involved in this study, their answers reflect generalized notions about the four other Gulf countries. Finally, although this is a comparative study, in most cases, KSA and UAE show few differences. 


\begin{tabular}{|c|c|c|c|}
\hline KSA & & UAE & \\
\hline Improve English language & 4 & Improve English language & 7 \\
\hline $\begin{array}{l}\text { Higher standard } \\
\text { education/qualification }\end{array}$ & 2 & Higher standard of education/qualification & 7 \\
\hline Learn more about different cultures & 8 & Learn more about different cultures & 2 \\
\hline Self-dependence & 10 & Self-dependence & 6 \\
\hline Communications skills & 5 & Get new experiences & 3 \\
\hline Learning various ways of learning & 3 & Different ways of thinking & 3 \\
\hline & & More chances of having better job & 3 \\
\hline & & Different perception about Westerners & 2 \\
\hline & & Expand the knowledge about the world & 6 \\
\hline
\end{tabular}
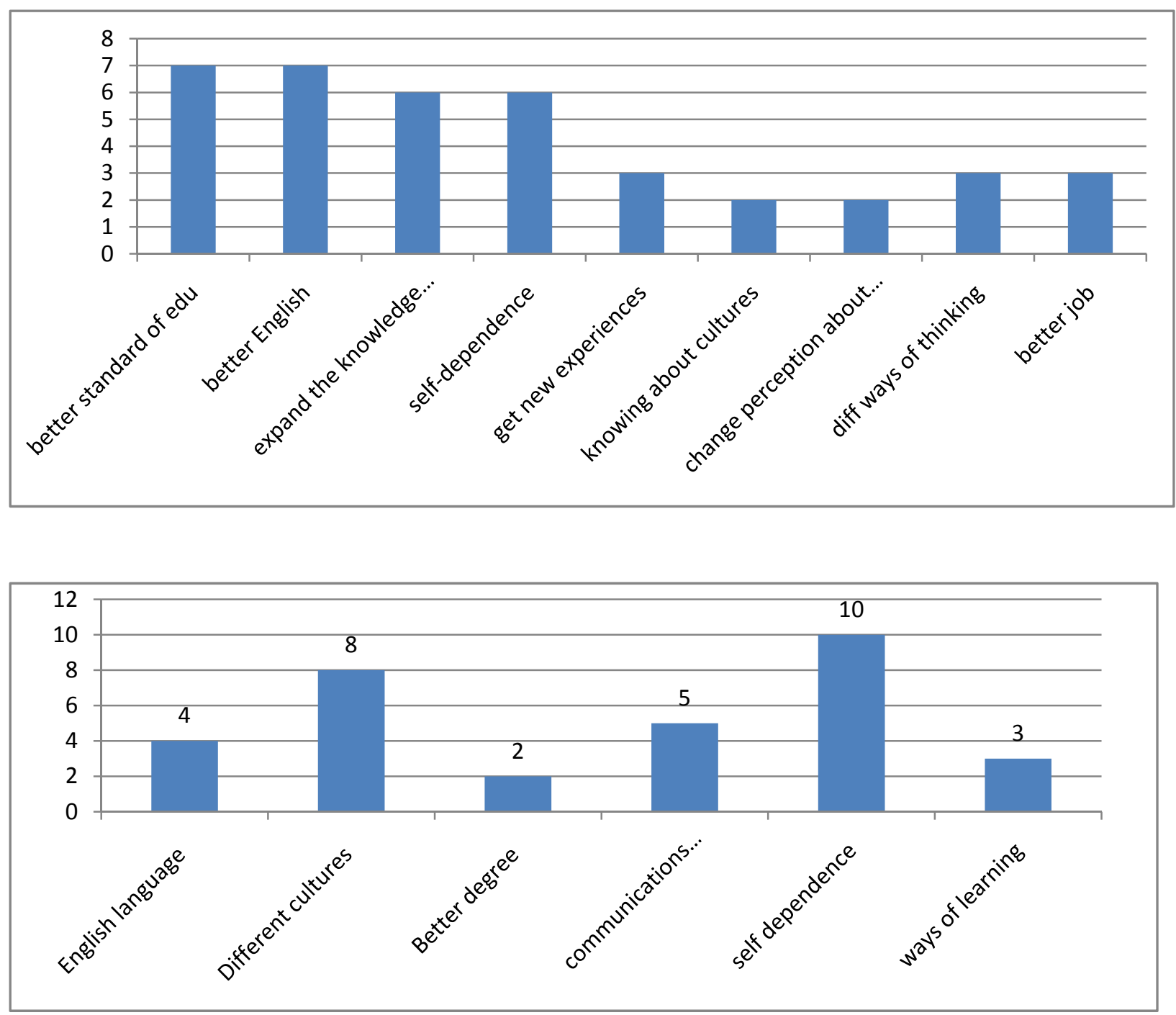

Figure 5. Personal benefits from studying overseas

UAE ( $n=14$ (all males))

$\operatorname{KSA}(\mathrm{n}=16(12$ male $/ 4$ female $)$ 
Because self-dependence seems to be very essential outcome for KSA's and UAE's students, it is important to clarify a few aspects of the life in those two countries. For instance, in KSA and simultaneously in UAE, around $85 \%$ of the workers are foreigners. Foreign workers are not only found in private business sectors but are also found in almost every household. For example, most of the families have more than one house servant/home maid to help households with the chores and to help them with looking after the kids. In some houses, one can find a home maid, a nanny, and a chef.

Foreign workers outside the house (i.e., the garden, car park and the yard) fall under the responsibility of drivers and gardeners. Usually, drivers wash cars, clean yards, and may also serve as house guardians. Since Saudi females are not permitted to drive their cars, more drivers are found in Saudi Arabia than in other Gulf countries. The business contracts with those assistants can be renewed every two years. So, they are more likely to be permanent servants or assistants.

Especially in KSA, some Saudi employees tend to hire low-wages professional foreign workers to do their household work. Moreover, in some cities of Saudi Arabia, they may even offer such services as launder clothes, deliver goods, or shop. In simple words, in Saudi Arabia, people - and in particular young people - are highly dependent and lack responsibility for basic household functions, while fathers, mothers and assistants deal with and look after most household issues. Hence "self-dependence" is the number one benefit.

Most importantly, and in the light of this research, the students' responses reveal their gratefulness and gratitude, in different expressions, for been given the chance to study abroad and get to know the world with their own eyes.

For example, 8 out of 10 Saudi students expressed their appreciation of being exposed to different place where they got the chance to know different people, cultures, and customs; and also to know how they think and live. The analysis also identified the importance of daily personal interactions between Saudis and different nationalities (in classrooms, shopping centers, hospitals, etc.) help to improve communication skills (which can close gap/s between different cultures) and to teach them about flexibility, tolerance, and cultural awareness; which can be "strategies for peace".

On a different matter, although Dubai (the biggest city of UAE) is an extensively multicultural city and English language is widely used there, the Emirati interviewees proclaimed that UAE is of no difference to KSA in terms of the modest usage of English language between the indigenous.

For Emirati students, improving English language proficiency and obtaining better or higher standards of education are considered to be the most important benefit from studying overseas. Being self-independent and expanding their knowledge about the world are considered secondary, although there is a slight distinction in terms of rankings.

Back to the scope of this research, Emirati students used different expressions referring to the gratitude of knowing different cultures. For example, 7 out of eight Emirati students point out that ones of the important outcomes of studying overseas are: 1- learning different ways of thinking - which indicates the increased level of the open-mindedness; 2- knowing more about different cultures as a result of the daily interactions; and 3changing their perceptions about the West (which were formulated based on the media). For essence, Emirati student 1 states: "My perception about the West was influenced and formed by the media; however, I have changed my mind after I came to Australia and I realized that they are lovely and friendly. They do not hate us!"

By coupling the responses from KSA's students and UAE's, it would appear that "student mobility" was a successful tool in fusing the gap/s between the East and West, at least from Arabs' perspective. To sum up the findings from Figure 5, one can observe that students are pleased with learning about different cultures, different people and different ways of thinking. Expanding their knowledge and experience are dedicatedly appreciated. In other words, students seem to show flexibility and improvement in terms of socialising and communicating with different people coming from different places and not as cautious as they were before the exposure.

\section{Verbatim Data from the Interviews}

\subsection{Saudi Students}

\section{Rana}

"This scholarship has given me a true chance to know different cultures... I was not aware of Chinese culture nor Colombian's culture... oh, in fact, I was not even aware of Australian's culture although I have been to many European countries, before I came to Australia for study".

"As you know, in Saudi Arabia, we have some unfavorable traditions that are not originated from our religion 
like for example hiding or keeping our mothers' names as secrets from other men... and some Saudi guys feel ashamed or insulted if they find their friends aware of their wives or mothers names... these things should change and I think overseas Saudi students will correct such norms... I mean to say Saudi people will be more open minded, I suppose!"

"Well, theses two years of my life have changed me a lot; I feel more self-confident now; I am more dependent unlike when I was in Saudi Arabia, I was relying on my parents, brothers and homemade to do what I have to do... but here I do everything and I am enjoying this. The other benefit... um, yeah, studying in Australia has also taught me how to work with groups. You know, I feel I become more mature, reliable and open-minded and I am expecting myself to be a very strong woman in the future with contribution to my country".

\section{$\operatorname{Njood} A$}

"In Saudi Arabia, as you know, we do not see international students in our universities so studying overseas has given me a very valuable chance to have friends from everywhere... I have Chinese, Japanese, Colombian, and from everywhere... I can't tell how much I am enjoying learning about their different cultures, food and traditions, it is amazing!".

"Well, if you see how the United States has build its glory and civilization, you will find that they used to import the enlightened minds, intelligent, talent and professional people from all over the world and they accommodate them in the States and provide them with their necessary and secondary needs only to encourage them to benefit the States and start its powerful. The other example is the United Arab Emirates... they import many foreigners to work for UAE until, you know, it becomes one of the most competitive countries in the world... I am trying to say, that USA and UAE needed enlightened minds and well educated people to establish their flourishing countries... and now, because we (Saudi students) are becoming better educated and we are having more creative minds, we will contribute to Saudi Arabia to be a real competitor with the First World countries".

Fayez

"Some overseas Saudi students have invented new things like medicines or a plane without pilot, or some other types of inventions... Canada for example is promoting its citizenship to those special Saudi students... eventually, those students will be improving the reputation of Saudi Arabia in the countries like Canada, USA, Japan, Australia, China and so on".

\section{Nojood B}

"Saudi Arabia has enough a lot of pure petrol/oil, but nonetheless we are still seen as a developing country... I think KSA has realized recently that we only need bright brains to invest, and that of course happens through sending its students to pursue their studies in different industrial, health, engineering or business areas, in the developed countries so that when those students return back to KSA, they will combine the money and high standard education to reestablish a new history of glory".

\section{Dania}

"I have learned a lot about many diverse cultures... and, I have learned about other religions as well... and now, I am more confident when talking to different people regardless their religion or background but rather I tend to create chances to talk to different people to learn more about their different lifestyle, cultures and so on and so forth".

"I find this scholarship very beneficial for us as 'Muslims' and for Saudi Arabia as a nation state... I know many good Saudi students who have successfully replaced the wrong perception of Saudi Arabia (as a country of desert, camels and terrorism) by a bright picture... or at least a better one. When we were studying English language courses, we were asked to give presentations about our countries and cultures and honestly, other students were amazed to know about us as what they have learnt from us is very different from they have learnt from the media".

\section{Anas}

"The language, I think, is the most annoying barriers in terms of communication... since this scholarship is requiring reasonable level of English language proficiency, the communication with others has become easier... ultimately, that will ease building stronger relationships with different people all over the world... I mean, the interactions between us and everyone else".

\section{Foad}

"I assume that KASP aimed to correct the stereotype of KSA after September $11^{\text {th }} \ldots$ many Saudi students, 
logically, through the good manners, in their different hosting countries, could clarified the stereotype of KSA and that we are not all extremists and that the majority of Saudis are friendly and open minded"

\section{Mazin}

"My perception about the West was influenced by the media. Studying here taught not to believe everything the media says about the West... I do not deny the high technology and development that Western countries have... but they still have many problems that we, thankfully, do not have in our countries... I am happy to learn in Australia but I am happier as I am an Arab".

\section{Mohammad}

"You know, the media always tries to convince us that all non-Muslims, especially Westerners hate us... and they are enemies of us... but, in fact, I found them very friendly and some of them do not even know where Saudi Arabia is located"

\section{Rashood}

"When I was studying English language courses, I was involved in many conversation and dialogues, with my international colleagues and sometimes teachers, about Islam and about the conservative system in Saudi Arabia... I noticed that most of the people have the same two questions: why, by laws of Islam, men can marry four wives and women cannot? And the other question is why women are not allowed to drive cars in KSA?

My Saudi friends and I were very friendly in clarifying these points besides some other points, of course... but I want to say that what if we are not sent to different places, would not those people kept captive to the media in the way they perceive us?... And, at the same time, we would have been kept as victims to the media too"

\section{Eissa}

"One of my extended family was one of the suicidal in the attack of the World Trade Center in $11^{\text {th }}$ of September... so, you know, I was frightened of going outside UAE... when my friends encouraged me to pursue my study overseas, they suggested USA, in the first place, but I said 'no way'... Even when I applied for one of Australian's universities, I was not hopeful and I was scared too as to what will happen to me outside my country because of that relative!!

When I arrived into the airport, in Australia, I was very cautious, and I was expecting the police in the airport to arrest me and deport me anytime... I couldn't believe it when I passed the security-check point and went outside the airport.

In the first months, I tended not to mention my last name so that people will not make any prejudgment... but over times, I felt more comfortable with socializing with everyone including Americans... and you know, I now feel okay to tell people that one of my relatives was involved in that horror attach but we are not the same... in the same family, one can fine good people and bad people".

\subsection{UAE Students}

\section{Ahmed}

"I think you know that Arab world is not really respected because the media is reflecting a-not-nice-picture about us... but I think now and with the scholarships, we (Arabs/Muslims) are exchanging information and socializing with other people... we are learning more about other cultures, and we are teaching them about others... so, I think, that will purify the reputation, relationship and stereotypes of Arab/Islamic world ultimately".

\section{Yusif}

"I have dreams about my country's future in terms of its international mutual respect and relationships... I hope, by now, many people around the world have recognized that we (Emiratis/Arabs or Muslims) deserve the respect because we human beings just exactly like others... and I hope, in 10 years time, developed countries will send its students to UAE to pursue their studies under the most advanced educational system in the world".

\section{Abdullah A}

"In the past, Emirati people do not communicate, or try to avoid communications with foreigners in UAE... we used to keep barriers between us and them, and we used to see them as strangers... but now, after I met different people from different countries, I feel like I respect all the foreigners in my country and I am keen to be more sociable with them".

"By living here [Australia], I have changed my perception [which generated from media] about the West... not everything they have is perfect... we are better in some life's areas". 


\section{Khalid}

"When we reflect good picture of our countries and of our religion, we will eventually contribute in tightening up the relationships between our Arab countries and Western countries".

\section{Hamad}

"I reckon that UAE will have a very strong relationships with the countries that are chosen as destinations for its students... for example, in the near past, Australians did not know much about UAE... but now, with Emirates and Etihad airlines, they know Dubai and Abu Dhabi... more than that, Australia and UAE are exchanging tourists; and we started to have partnerships with Australian's universities like Wollongong".

\section{Abdullah B}

"In the past, I used to refuse traveling with my friends to any European country or, to be precise, to any Anglophone country; for two reasons: first, because I was not speaking good English, and second, because I was afraid of being discriminated against as am Arab and Muslim... but now, I am not afraid any more but rather I'm excited to discover and see more countries and learn about more cultures".

"Emiratis will be as qualified as foreign workers so, UAE will prioritize us over foreign workers... which will, eventually, reduce the number of foreign workers in UAE".

\section{Mohammad}

"I think... one of the most important benefits for myself as well as for UAE is to help some people here (in Australia) to change the false impression and negative perceptions about Arab states... you know, there were a few Emiratis involved in September $11^{\text {th }} \ldots$ my friends and I are happy to make strong relationships with those students whom used to be afraid of us and now like and trust us".

\section{Implications from this Research}

Inspired by the experience of students in a Palestinian/Israeli study (Salomon, 2004) and from the context of the interviews in the current study, it would seem that bringing or gathering the two sides of a conflict 'under one roof' and give them the chance to work or socialise together works effectively in breaking some fears and in replacing hatred with friendship.

Drawing upon the implications of this data, the researcher suggests that peace education can take two forms in order to be effective and fruitful. One is to promote peace education as a compulsory subject everywhere or at least where major misunderstandings and tensed relationships occur. While it is believed that each conflict derived from lack of knowledge or dissimilarities, students must recognise that humans with their differences in skin colour, religions, languages, perspectives, etc are painting a highly enriched, beautiful and colorful "picture" which is, by far, nicer than one which is 'black' of plain 'white'.

Student mobility comes into sight as another form: transporting students from their region/countries into others which they formerly avoided and feared because of political and other factors; and studying overseas, per se, is a worthwhile experience that virtually everyone seeks. It gives one of the fearful groups a chance to mingle, listen, talk, know, learn, live and experience 'the other side'. Ultimately, this interaction between nations/groups is effectively bridging gaps.

\section{The Promise of Peace Education}

Accordingly, it appears that most of the methods of promoting peace education are via schooling institutions. However, one might wonder to what extend can that be helpful?

For instance, post 9/11, some of Muslim countries have been enduring different kinds of difficulties at the national level and personal level. Those difficulties or conflicts happened between Muslims and Westerners - especially with America due to the fact that the attack took place in their country. As things escalated at that point in time, a large number of innocent Muslims began to be fearful of being attacked. The situation reflected the following comment by Salomon:

Emanating from the collective narrative are sets of beliefs that each side holds, usually mirroring the views held by the other side... Typical beliefs are that "we" are right but "they" are wrong; "we" are the victims, whereas "they" are aggressors; "we" only respond, thus even when "we" do harm, "they" are to blame; "we" are moderate, whereas "they" are radical; or "they" understand only the language of force (Salomon, 2004, p. 259).

The image here reflects two sides/parties that are isolated from one another and could hardly understand or hear one another! 


\section{Conclusion}

This research attempts to link learning behavior, knowledge conversion, and personality development as necessary components to understanding peace. It did not in any way pursue peace education as a form of curriculum but rather investigated the psychological, sociological, and anthropological dispositions necessary for education (self-education) to take place. Despite the fact that student mobility was identified as a educational tool for peace (within the context of improving international awareness and expanding one's global competence), certain challenges for peace and reconciliation must still be overcome. According to Delors (1996, pp. 15-16), tensions will continue to between:

- The global and the local: people need gradually to become world citizens without losing their roots and while continuing to play an active part in the life of their nation and community

- The universal and the individual: culture is steadily being globalized, by as yet only partially. We cannot ignore the promises of globalisation nor its risks, not the least of which is the risk of forgetting the unique character of individual human beings

- Tradition and modernity: people need to adapt to change without turning one's back on the past, but how can autonomy be acquired in complementarity with the free development of others and how can scientific progress be assimilated?

- Long- and short-term considerations: predominance of the ephemeral and the instantaneous, in a world where an over-abundance of transient information and emotions continually keeps the spotlight on immediate problems

- The need for competition and the concern for equality of opportunity: reconciliation of three forces: competition, which provides incentives; co-operation, which gives strength; and solidarity, which unites

- The extraordinary expansion of knowledge and human beings' capacity to assimilate it: making choices, providing ways to improve lives through knowledge, experiment, and development of their own personal cultures

- The spiritual and the material: the noble task to encourage each and every one, acting in accordance with their traditions and convictions and playing full respect to pluralism, to lift their minds and spirits to the plane of the universe and, in some measure, to transcend themselves.

Despite these challenges, people cannot question nor underestimate the role of education as a tool for peace.

\section{References}

Ackerman, C. M. (2009). The essential elements of Dabrowski's Theory of Positive Disintegration and how they are connected. Roeper Review, 31(2), 81-95.

Alsharif, A. (2011, May 10). Update 2-Gulf bloc to consider Jordan, Morocco membership. Reuters. Retrieved March 20, 2012, from http://af.reuters.com/article/moroccoNews/idAFLDE7492I020110510

Alvarez-Calderon, L. M. (2010). Man as value: From consciousness to morality. Retrieved from http://www.heksis.com

Anthology by Harvard College Fellows and administrators. (1998). Are you listening? Voices from Middle East. Cambridge, MA: Harvard University.

Azcona, M. C. (2005). Peace Education Through Literature. In A. Aharoni (Ed.), Peace, Literature and Art. Encyclopedia of Life Support Systems (EOLSS), Developed under the Auspices of the UNESCO, Eolss Publishers, Oxford, UK. Retrieved from http://www.eolss.net

Basiga, B. (2004). Globalization and Peace Education. Canadian Social Studies, $38(3), 18$.

Breitmayer, B. J., Ayres, L., \& Knafl, K. A. (1993). Triangulation in qualitative research: Evaluation of completeness and confirmation purposes. Image: Journal of Nursing Scholarship, 25, 237-243.

Dabrowski, K. (1964). Positive Dinsintegration. Boston, MA: Little, Brown \& Company.

Davison, H. R. (1960). Where is the Middle East? Foreign Affairs, 38, 665-675.

Delors, J. (1996). Learning: The Treasure Within. A report to UNESCO of the International Commission for the Twenty-first Century. Paris: UNESCO Publishing.

Denzin, N. K. (1970). The research act: A theoretical introduction to sociological methods. Chicago: Aldine.

Diorio, J. A. (1989). Consequentialism and peace education. New Zealand Journal of Educational Studies, 24(1), 
19-33.

Featherstone, M. (1995). Undoing Culture: Globalization, Postmodernism and Identity. London: Sage Publications.

Feyerabend, P. (1987). Farewell to Reason. London: Verso Publishers.

Foster, R. L. (1997). Addressing epistemologic and practical issues in multimethod research: A procedure for conceptual triangulation. Advancesin Nursing Science, 20(2), 1-12.

Fountain, S. (1999). Peace Education in UNICEF (Working Paper No. PD-ED-99/003). Retrieved from http://portal.unesco.org/pv_obj_cache/pv_obj_id_331AADB8B0E723F81025DEC44EA7562D52400600/fi lename/PeaceEducationUNICEF.pdf

French, S. (2000). Re-scaling the economic geography of knowledge and information: Constructing life assurance markets. Geoforum, 31(1), 101-119. Retrieved from http://www.sciencedirect.com/science/article/pii/S0016718599000457

Green, J., \& Thorogood, N. (2004). Qualitative Methods for Health Research. London: Sage.

Harris, I. (2008). History of Peace Education. In M. Bajaja (Ed.), Encyclopedia of peace education. Information Age.

Harris, I., \& Morrison, M. L. (2003). Peace Education. North Carolina: McFarland Company.

Hochschild, J. (2006). Globalization: Ancient and Modern. The Intercollegiate Review, 40-48.

Jan, M. (2009). Globalization of Media: Key Issues and Dimensions. European Journal of Scientific Research, 29(1), 66-75.

Ladson-Billings, G. (1995). But that's just good teaching!: The case for culturally relevant pedagogy. Theory into Practice, 34(3), 159-165.

Mendaglio, S. (2008b). The Theory of Positive Disintegration (TPD) and other approaches to personality. In S. Mendaglio (Ed.), Dabrowski's Theory of Positive Dinsintegration (pp. 249-274). Scottsdale, AZ: Great Potential Press.

Minichiello, V., Aroni, R., \& Hays, T. (2008). In-Depth Interviewing. Sydney: Pearson Education Australia.

Mowlana, H. (1985). International Flow of Information: Global Report and Analysis. Paris: UNESCO.

Mowlana, H. (1993). Towards a NWICO for the Twenty-First Century. Journal of International Affairs, 47(1), 59-72.

Norris, P., Kern, M., \& Just, M. (2003). Framing terrorism: The News Media, the Government and the Public. New York and London: Routledge.

Opper, S., Teichler, U., \& Jerry, C. (1990). Higher Education Policy Series 11: Vol. II. Impacts of Study Abroad Programmes on Students and Graduates. London: Jessica Kingsley Publishers.

Polanyi, M. (1966). The Tacit Dimension. Garden City, New York: Doubleday \& Company.

Reardon, B. A. (2002). Human Rights and the Global Campaign for Peace Education. International Review of Education, 48(3-4), 283-284.

Reich, S. (1998, December). What is Globalization? Four Possible Answers (Working Paper no. 261). Retrieved January 30, 2013, from http://kellogg.nd.edu/publications/workingpapers/WPS/261.pdf

Remler, K. D., \& VanRyzin, G. G. (2011). Research Methods in Practice: Strategies for Description and Causation. Thousand Oaks, California: SAGE.

Salomon, G. (2004). Does Peace Education Make a difference in the Context of an Intractable Conflicts? Peace and Conflicts. Journal of Peace psychology, 10(3), 257-274.

Sandy, L. R., \& Ray, J. P. (2002). The Nature of Peace and Its Implications for Peace Education. Peace and Conflict Resolution, 4(2), 1-8.

Savery, J. R., \& Duffy, T. M. (2001, June). Problem Based Learning: An instructional model and its constructivist framework. CRLT Technical Report, No 16-01.

Schostak, J. (2006). Interviewing and Representation in Qualitative Research. New York, NY: Open University Press.

Sturm, M., \& Siegfried, N. (2005, June). Regional Monetary Integration in the Member States of the Gulf 
Cooperation Council. Frankfurt am Main, Germany: European Central Bank. ISSN 1725-6534. Occasional Paper Series, No. 31. Retrieved March 22, 2012, from http://www.ecb.int/pub/pdf/scpops/ecbocp31.pdf

\section{Note}

Note 1. Gulf Arabs are the Muslim Arabs who live in Gulf Arab States (The Kingdom of Saudi Arabia, United Arab emirates, Oman, Bahrain, Qatar and Kuwait). A very few scholars could differentiated Gulf States region from Middle East (such as Anthony Welch), whereas the majority of the writers refers to Gulf States as part Middle East as well. 